\title{
What has become of critique? Reassembling sociology after Latour ${ }^{1}$
}

\section{Word count: 8,986}

\begin{abstract}
This paper offers a defence of sociology through an engagement with Actor Network Theory (ANT) and particularly the critique of 'critical' and politically engaged social science developed by Bruno Latour. It argues that ANT identifies some weaknesses in more conventional sociology and social theory, and suggests that 'critical' and 'public' orientated sociologists can learn from the analytical precision and ethnographic sensibilities that characterise ANT as a framework of analysis and a research programme. It argues, however, that Latour et al have too hastily dispensed with 'critique' in favour of a value neutral descriptive sociology, and that the symmetrical and horizontalist approach adopted in ANT is particularly ill-suited to the development of scientific knowledge about social structures. It argues that a more straightforwardly realist sociology would share many of the strengths of ANT whilst being better able to interrogate, empirically and normatively, the centres of contemporary social power.
\end{abstract}

Keywords: Bruno Latour, actor network theory, critical sociology, critique, realism, social structure.

In the wake of the civil rights movement and the political upheavals of the 1960s, sociology assumed an increasingly critical orientation towards its object of study. In the United States, radical scholars challenged 'mainstream' sociology, most famously in Martin Nicolaus's outspoken address to the American Sociological Association in 1968 (Fuller 1996; Ross 2010), and in Britain the political tumult of that period saw a similar shift away from Parsonian functionalism and towards an explicitly critical sociology influenced by C. Wright Mills and various Western Marxist intellectual currents (Halsey 2004: 117). If this radicalism 
soon receded, it nevertheless marked the beginnings of a 'critical drift' in Anglophone sociology (Burawoy 2005: 6). In France, meanwhile, various ‘critical trends' similarly became prominent in '60s and '70s sociology inspired by Marxism and the Frankfurt School (Boltanski 2011: 18), whilst Bourdieu - who had a more distant relationship with Marxism and the 'New Left' (Swartz 2003) - led the development of an influential variant of 'critical sociology' that would go on to have a significant impact on British sociology (Outhwaite 2009).

The explicitly 'critical' orientation of a good deal of post-60s sociology has naturally been challenged, and not only by proponents of the 'professional' and 'policy' sociology (Burawoy 2005) the radical sociologists sought to problematise. In the case of French sociology, the Bourdieusian paradigm, with its strong emphasis on domination, has been widely criticised for downplaying the critical capacities of actors, whilst inordinately elevating the status of professional sociologists (Boltanski 2011: 19-23). Boltanski's 'pragmatic sociology of critique' is a notable departure. But Boltanski, a former colleague of Bourdieu's, has remained committed to sociology as a 'critical' discipline for the betterment of society (Boltanski, Honneth and Celikates 2014: 572). A far more radical break with 'critical sociology' has been advocated by Bruno Latour, the leading figure in Actor Network Theory (ANT). Latour is increasingly influential in Anglophone scholarship (Elder-Vass 2014) and, Inglis suggests (2014: 104), may be set to ‘dislodge Bourdieu's canonical reputation and replace him... as British sociology’s new most-favoured Frenchman’. Latour has set himself squarely against the very notion of critique, indeed he is treated by Noys (2014) as an exemplar of 'anticritique'. The most striking example of this is a highly cited article written in the wake of the US-led invasion of Iraq in which Latour rhetorically and repeatedly posed the question: 'what has become of critique?'. He attacked the 'critical barbarity' of anti-war voices and likening academic work using the language of 'power, 
society, [and] discourse' - naming Bourdieu specifically - to 'conspiracy theory' (Latour 2004: 229). This critique of 'critical sociology', which reached its apogee with that piece, is implicit and explicit in much ANT scholarship, and is most developed in Latour's Reassembling the Social, in which he laments the 'gratuitous use of the concept of power by so many critical theorists' (Latour 2005: 85).

Through an engagement with the ideas of Latour and his fellow travellers, this paper offers a defence of sociology and 'critical sociology' in particular. It suggests that the analytical insights at the heart of ANT correctly identify some weaknesses in more conventional sociological work, and that sociologists can learn from the analytical precision and ethnographic sensibilities that characterise ANT as a framework of analysis and a research programme. It argues, however, that ANT has overemphasised the fluidity of social structures and too hastily dispensed with 'critique' in favour of a value neutral, descriptive sociology; and that the conceptual vocabulary Latour et al have developed is ill-suited to social scientific research in an era characterised if not by stable 'structures', then certainly by persistent, and growing, institutionalised inequalities and concentrations of power (Piketty 2014).

\section{What is Actor Network Theory?}

A ‘disparate family' of 'tools, sensibilities and methods of analysis' (Law 2009: 141), what became ANT first emerged in the late 1970s and early 1980s out of the anti-positivist, antifoundationalist works of Science and Technology Studies (STS), which laid the groundwork for ANT's rather idiosyncratic methodology and framework of analysis. According to Law, it was then sometime around the late 1980s or early 1990s that ANT 'achieved recognizable form as a distinctive approach to social theory.' (Law 2009: 146) ANT has been known by a number of other terms - among them 'enrolment theory', 'the sociology of translation' and 'material semiotics'. Actor Network Theory, which seems to have stuck, was a label roundly 
rejected by Latour in 1999 (Latour 1999: 15), only to be endorsed again six years later (Latour 2005: 9).

A seminal text for the development of ANT was Latour and Woolgar's Laboratory Life: The Social Construction of Scientific Facts (1979), one of a number of ethnographic studies of scientific work produced during the 1970s that was influenced by Thomas Kuhn's Structure of Scientific Revolutions. Kuhn, Fuller notes, 'started with the idea that science is nothing more (and nothing less) than what scientists do' (Fuller 2000: 2), and following Kuhn, protoANT scholars treated science as a cultural practice (Law 2009: 143), and the scientific process as 'a kind of craftwork' (Law and Singleton 2013: 486). In Laboratory Life, Latour and Woolgar argued that scientific facts are not 'discovered' but 'constructed' through 'the daily activities of working scientists' (Latour and Woolgar 1979: 40). The book describes the sometimes mundane processes through which the actions and interactions of scientists eventually produce 'facts', focusing particularly on the transcription and circulation of findings in scientific papers. Law notes that though the authors of Laboratory Life do not use the term 'actor-network theory' (indeed Woolgar does not identify as an ANT scholar), 'many of its elements are present' (Law 2009: 144).

Kuhn's Structure of Scientific Revolutions also influenced the so called 'strong programme' in the sociology of scientific knowledge, which pioneered an influential methodological relativism, which in turn influenced ANT. The 'strong programme' advocated adopting an 'impartial' position with regard to truth or falsehood and rational or irrational theories and explanations, and a 'symmetrical' approach to analysing their social impact. The symmetry principle, Bloor explains,

was formulated in opposition to an earlier prevailing assumption, still defended in many quarters, which has it that true (or rational) beliefs are to be explained by 
reference to reality, while false (or irrational) beliefs are explained by reference to the distorting influence of society. (Bloor 1999: 84)

'The idea,' Collins and Yearley note, 'was that the construction of the boundary between the true and the false would become the topic rather than the starting point' (1992: 302).

Latour proffers a very similar 'rule' for the treatment of scientific controversies in Science in Action (Latour 1987: 99). In ANT, the 'symmetrical' approach is adopted and adapted, with the language of 'truth' abandoned in favour of an approach that sees scientific facts as being 'constructed' when a scientist can convince others that an object (or a 'spokesperson' of a group of objects) conforms to a particular theory. This is described in terms of the object, as well as other people and objects, being 'enrolled' into an explanatory scheme. Though there are obvious similarities with the 'strong programme' here, there is also a subtle and important difference in emphasis. As Seguin succinctly puts it, Bloor and his 'strong programme' associates were interested in the social factors influencing scientific work, whilst ANT emerged from an examination of science in society (Seguin 2000). To simplify somewhat, Latour and other ANT scholars viewed scientific facts as 'constructed' not by society, nor by distinctive factors which can be described as social (or political), but by scientists and the human and non-human objects with which they interact. Latour, Seguin notes, thus initiated an important shift from examining 'the social determinants of scientific knowledge to the ontological labour performed by scientific activity' (Seguin 2000). As Latour himself puts it, ANT 'does not deal with the nature of knowledge, with things-in-themselves, but with the way all these things are tied to our collectives and to subjects.' (Latour 1993: 4) This allowed ANT to avoid both positivist and radical constructivist approaches in its account of the interrelationship between scientists, the facts and theories they produce, the objects and phenomena they describe, and the non-scientific world with which they interact. Thus unlike positivist approaches, ANT does not appeal to notions of truth in describing how scientific 
consensus is developed. But unlike radical constructivist approaches appealing exclusively to linguistic or discursive practices, it remains empirical and (Law in particular insists) materialist.

Law suggests that ANT 'can be understood as a powerful set of devices for levelling divisions usually taken to be foundational.' (Law 2009: 147) It is best known for having 'opened the social sciences to non-humans' (Callon 1998a). In Science in Action, Latourappropriating the language, if not the analysis, of the 'strong programme' - argued that social scientists should 'consider symmetrically the efforts to enrol human and non-human resources' (Latour 1987: 258). The celebrated example of this is Callon's paper detailing a plan by a handful of research scientists to repopulate scallops in a coastal bay in France (Callon 1986); an 'exemplary actor-network case-study... notorious because Callon analyses people and scallops in the same terms.' (Law 2009: 145) A good example of ANT's science in society approach, Callon's paper treats the scallop larvae used in the scientists' field work and the fishermen's union who the scientists sought to convince, each as representatives, 'spokespersons', of a group whom the scientists were attempting to 'enrol' in their project (Callon 1986). Humans, animals, objects and technology are thus all treated by Callon as interrelated 'actants' (as opposed to 'actors' which is suggestive of human agency). Importantly in terms of epistemology, concepts also form an integral part of what Callon calls sociotechnical agencements (an arrangement or assemblage of people and objects):

A sociotechnical agencement includes the statement(s) pointing to it, and it is because the former includes the latter that the agencement acts in line with the statement, just as the operating instructions are part of the device and participate in making it work. Contexts cannot be reduced, as in semiotics, to a pure world of words and interlocutors; they are better conceived as textual and material assemblages. (Callon 2007: 320) 
Woolgar (Latour's Laboratory Life co-author) has written that the symmetrical treatment of humans and objects is 'one instance within a larger dynamic: the successive rooting out and dismantling of fearful symmetries... in a glorious bonfire of the dualities.' (quoted in Pels 2003: 133) Following their stated principles of generalised symmetry and free association, ANT scholars have disavowed not only the conventional methodological distinction between humans and non-humans, but relatedly also the conventional analytical distinction between politics or society on the one hand, and science, technology or nature on the other. These conventionally distinct realms, Latour argues, are in reality inextricably intertwined, and it makes no sense to analyse either in isolation from the other (Latour 2005: 75-6).

\section{The ANT critique of sociology}

Building on this innovative approach to the sociology of science, ANT scholars have developed a critique of more conventional social science, including Durkheimian and positivist sociology, and 'critical sociology' in particular. Key sociological categories capitalism, power, classes - are understood in ANT as arbitrary and 'demoted and treated as the effect of translations' (Law 2009: 147). The critique of sociology is most forceful and provocative in Latour, who charges that the discipline imposes its analytical categories on its research subjects, interpreting reality in accordance with its arbitrary conceptual tools.

Latour says his ethnographic work for Laboratory Life led him to break with approaches to the sociology of science that challenge the epistemic privilege of science by attempting to uncover latent social factors influencing the production of scientific knowledge. This led him to later reject altogether the notion that 'society' or 'the social' can serve as meaningful analytical categories. In the second edition of Laboratory Life, the word 'social' was dropped from the subtitle. Latours recalls: 
ANT started with research into the history and sociology of science, tried first to provide a 'social' explanation of scientific facts, failed to do so, and then, from this failure, it drew the conclusion that it was the project of a social explanation of anything that was itself wanting. (Latour 2003: 35)

Sociology, Latour claims, has assumed that 'every activity - law, science, technology, religion, organization, politics, management, etc. - could be related to and explained by the same social aggregates behind all of them', whilst ANT by contrast assumes that 'there exists nothing behind those activities even though they might be linked in a way that does produce a society - or doesn't produce one.' (Latour 2005: 8) Callon, expressing the point in less bold terms, writes that ANT shares with constructivist sociology the view of society as 'an achievement', as opposed to 'structuralist sociology, which regards society as the medium in which actors are immersed and sometimes drowned!' (Callon 1998c: 267, n.5) For ANT scholars, the conventional categories of social science can legitimately serve as a descriptive short hand for certain phenomena, but cannot serve as explanations. In Reassembling the Social, Latour is particularly scathing of 'critical sociology' which he claims is defined by the following three traits: it doesn't only limit itself to the social but replaces the object to be studied by another matter made of social relations; it claims that this substitution is unbearable for the social actors who need to live under the illusion that there is something 'other' than social there; and it considers that the actors' objections to their social explanations offer the best proof that those explanations are right. (Latour 2005: 9)

Callon has developed a parallel critique of sociology in his work on markets and the 'performativity' of economics (distinct from the concept popularised by Judith Butler in feminist post-structuralism (Butler 1990; 1997)), charging that economic sociologists have 
ignored the reality of markets, stubbornly insisting that market actors are influenced by extraeconomic, social, factors (Callon 1998b: 51).

\section{Learning from Latour}

Have sociological categories like power and society 'outlived their usefulness', as Latour suggests (2004, 229-30)? Has he, with a little help from his friends, initiated a revolutionary shift in social science? And if so, what will be left of what Latour calls 'critical sociology' after the revolution of the ANTs? There are good reasons to be sceptical about any wholesale adoption of ANT, for reasons that will be further elucidated. But its proponents have certainly identified a number of problematic tendencies in social science and social theory which if addressed would strengthen sociological methods and analysis.

Let's begin with the analytical innovation for which ANT is best known: the 'symmetrical' treatment of humans and non-humans. From a distance this can seem like a fatuous move. But if contextualised within the development of STS it can be understood as reintroducing a degree of realism to a research programme which whilst rooted in a 'materialist' approach has focused excessively on epistemology. ${ }^{2}$ ANT essentially sidesteps the epistemological questions that have detained many STS scholars by focusing on the empirical question of how humans, non-humans, and ideas about both, are enrolled into 'symmetrical' networks or 'assemblages'. The methodological symmetry this approach entails does not imply that the human and inanimate objects (for example) that make up such assemblages are the same, nor that they should be treated as such. But it does insist that animals, minerals, manmade objects and technologies should be seen as 'acting' in the sense that they have an effect, or are afforded what critical realists call causal powers. This means recognising not only that scientists, social scientists included, produce and exchange socially situated ideas about the world, but also that, as Herbert Blumer put it, 'the empirical world can "talk back".... in the sense of challenging and resisting, or not bending to, our images or conceptions of it.' 
(Blumer 1986: 22) It also means recognising that non-human objects are capable of transforming what Latour resists calling society. And who would doubt that mobile phones and the internet, for example, have been transformative? Or that the earlier invention of the printing press, the radio, or the Maxim gun profoundly reshaped the world. That sociologists have tended to overlook the 'agency' of technology in favour of examining how people and social institutions relate to each other and create meaning is a point well taken, and from the perspective of empirical sociology, the realist shift underlying the symmetrical philosophy that is the shift from focusing on ideas about things to an ontology which incorporates ideas about things and things in themselves - can only be a welcome step. ${ }^{3}$

A further analytical payoff from this move is that there is no conceit in ANT that the social scientist and her analysis stands apart from the world, whilst the objects of investigation remain embedded within it. This insight is most developed in the work of Callon and others on the 'performativity' of economics, which has already been referred to. It is well expressed by Mitchell, who writes that rather than assuming that 'the work of social science is to represent a material world external to itself', we should understand it as providing 'a set of instruments of calculation and other technical devices, whose strength lies not in their representation of an external reality but in their usefulness for organizing sociotechnical practices.' (Mitchell 2007: 244) This perspective, which in fact is not mutually exclusive with holding that social scientists represents the world in their work, allows for a reflexivity in sociological work which Bourdieu saw as central to the discipline's scientific status, and which - since it fundamentally undermines notion of political neutrality - also sits well with conceptions of sociology as a politically engaged discipline.

Related to ANT's controversial development of the symmetry principle is its rejection of what Latour calls the 'sociology of the social', a term that would seem to be directed against the Durkheimian tradition as much as explicitly critical approaches. Again, this is rooted in 
ANT's break with STS, but it was subsequently developed into a much more ambitious attack on social science. For Latour, when social scientists speak of 'society' they 'have mistaken the effect for the cause... what is glued for the glue.' (1986: 276) We cannot, Latour argues, work backwards from society to individuals, from structure to agents, from the macro to the micro, since these are all arbitrary and misleading binary categories (Latour et al 2012). Society, for Latour, does not exist. Neither, for that matter, does power, the central concept in critical sociology. Both are considered to offer little insight into our understanding of really existing assemblages of 'actants'.

This argument can be taken as a cogent critique of the tendency of scholars to reify their concepts and models. This is a tendency perhaps most advanced in macro-economics, which has conjured up an object, 'the economy', that is really an abstraction of a fairly arbitrary set of metrics. Latour's critique, however, is directed primarily at sociologists. This itself raises questions that we shall return to, but he is surely correct that in its more functionalist varieties at least, sociology has reified 'society' in much the same way in which economists have 'the economy'. Indeed, we find powerful critiques of precisely this dynamic in the work of some influential 'sociologists of the social'. Wacquant, for example, a former collaborator with Bourdieu - who would seem to be the main target of Latour's polemics against 'critical sociology' - warns that

The chief danger of the objectivist point of view is that, lacking a principle of generation of those regularities [materially observed, measured, and mapped out], it tends to slip from model to reality - to reify the structures it constructs by treating them as autonomous entities endowed with the ability to 'act' in the manner of historical agents. ... It thus destroys part of the reality it claims to grasp in the very moment whereby it captures it. Pushed to its limits, objectivism cannot but produce an ersatz subject, and portray individuals or groups as the 
passive supports of forces that mechanically work out their independent logic. (Bourdieu and Wacquant 1992: 8)

Another notable critic of functionalist and structuralist sociology is Michael Mann, who in contrast to Latour puts the concept of power at the very heart of his work. Mann opens his Sources of Social Power with the following statement:

Societies are not unitary. They are not social systems (closed or open); they are not totalities. We can never find a single bounded society in geographical or social space. Because there is no system, no totality, there cannot be 'subsystems,' 'dimensions,' or 'levels' of such a totality. ... Because there is no totality, individuals are not constrained in their behavior by 'social structure as a whole,' and so it is not helpful to make a distinction between 'social action' and 'social structure.' (Mann 1986: 1-2)

Latour's critique, however, is more radical. For him, the 'ersatz subject' referred to by Wacquant is no more or less real or concrete than the human subject. Both are made real by virtue of being successfully 'enrolled' into 'assemblages' of 'actants' - 'assemblages' which must be examined holistically and symmetrically. Thus, whilst Mann draws heavily on conventional categories of social science - most of all power - in his ambitious historical sociology, ANT shares with post-structuralist thought a profound suspicion of such categories.

ANT differs from post-structuralist scholarship though in that it is much more firmly rooted in empirical work and has conversely been much less theoretical, its idiosyncratic conceptual vocabulary notwithstanding. This has been noted by Law, who writes that ANT can be 'understood as an empirical version of post-structuralism' and remarks that its 'logic is not far removed from Foucault's' (Law 2008: 623). Latour too acknowledges the similarities 
with Foucault, whose 'genius' he claims has been lost in (the English) translation. Having provided an 'analytical decomposition of the tiny ingredients from which power is made', Latour argues, the 'transatlantic destiny of Michael Foucault' was to be 'turned into the one who had "revealed" power relations behind every innocuous activity' (Latour 2005: 86 n.106). Latour's argument here is that Foucault's accounts of the discourses and practices of domination have wrongly been treated as if they revealed some essence operating behind such relations that we can label 'power'. Again, for Latour, there is nothing 'behind' assemblages, there are only the actor-networks.

Whilst sharing the resolute anti-foundationalism of post-structuralism, and the same impulse to deconstruct concepts rather than construct a body of knowledge, ANT's great strength is its retention of something like a realist ontology, which has meant that ANT scholars, and those influenced by ANT, have produced some accomplished empirical work which has avoided the customary binaries of conventional social science. Noys, a critic of ANT, approvingly (though not without reservations) cites the work of Weizman (2007) on the architecture of the Israeli occupation, and Mitchell $(2002 ; 2011)$ on colonialism, modernisation and fossil fuels (Noys 2014: 220-203), and there are many other scholars who have produced innovative studies by following to some extent the 'Latourian path of dereifying structures of dominance by tracing the networks and forms that constitute it' (Noys 2014: 201), the work of Fabian Muniesa and his collaborators on business pedagogy and capitalisation being another recent example (Muniesa 2014; Muniesa 2016; Muniesa et al 2017). Rather than invoking 'mysterious structure', researchers, Latour argues, should examine 'fully visible and empirically traceable sites' (Latour 2005: 179):

whenever anyone speaks of a 'system', a 'global feature', a 'structure', a 'society', an ‘empire', a ‘world economy', an ‘organization', the first ANT reflex 
should be to ask: 'In which building? In which bureau? Through which corridor is it accessible? (Latour 2005: 183)

There is some resonance here, in terms of the attention to the concrete, and even the mundane, with the body of sociological work taking inspiration from Foucault's concept of 'governmentality' (e.g. Rose and Miller 2008), but without the excessive focus on power, which Latour laments in the transatlantic followers of Foucault. This brings us to the key question of power that is so central to 'critical sociology' and how it should be researched and theorised. The consequences of ANT's novel analytical framework is that one must not explain forms of power one encounters in research with reference to macrosociological categories like capitalism, imperialism or patriarchy, but rather should detail concretely how such relations are represented and enacted. Latour describes power as 'as a stop gap solution to cover our ignorance, to explain (away) hierarchy, obedience or hegemony' (Latour 1986: 266). Contrary to many sociological definitions and popular conceptions, power, Latour argues, 'is not something you may possess and hoard', since it can only be evidenced in its effects. But neither can it strictly speaking be exercised by those said to possess it, since it always depends on the actions of others. There is again some resonance here with Foucault and his insistence that power is 'never in anybody's hands, never appropriated as a commodity or piece of wealth... [but is] exercised through a net-like organization.' (Foucault 1980: 98) Latour, however, takes this argument in a different direction, reasoning that the concept of power may 'be used as a convenient way to summarise the consequences of a collective action, [but] it cannot also explain what holds the collective action in place.' (Latour 1986: 265) This argument is the same basic formulation as Latour's critique of 'society' or 'the social'. In Harman's summation, power, which he describes as having an 'occult quality' in the work of 'radical political critics', should be understood as 'a result rather than a substance' (Harman 2009: 21), meaning that to explain anything using the term 
is 'an act of intellectual laziness.' (Ibid.: 27) What we call 'power', Latour forcefully argues, is, like 'society', an effect of a particular arrangement of people, ideas and objects, and it is these particular arrangements that should be the subject of sociological investigation.

What are proponents of what Latour disparagingly calls 'critical sociology' to make of this argument? Latour is surely correct when he says that describing an individual or institution as powerful in itself tells us little about how and why it is able to exert greater influence than others. And if the purpose of sociology is to understand such processes then it follows that sociologists, rather than using 'power' as a substantive explanatory category, should use the concept as a starting point for the empirical investigation of the particular mechanisms at work.

This is one of a number of useful insights in ANT. As we have seen, it offers a convincing critique of functionalist and structuralist sociology, and the broader tendency within the social sciences, and 'critical' work in particular, to reify analytical models. Its interrogation of conventional social scientific categories; its recognition that social scientific ideas and models are not simply representations, but agents of social change (to express the point in more conventional terms); and its analytical exactitude and ethnographic precision can all serve to strengthen sociological theory and practice. Latour's claim, however, is not that the research programme he leads can offer original and useful insights that might reinvigorate sociological analysis. It is rather that the whole enterprise needs to be radically reassembled. The 'social', which Latour takes to be the object of sociology, is, he claims, 'a superfluity, a purely redundant rear-world adding nothing to the real world except artificial conundrums just like the ether before relativity theory' (Latour 2005: 107). This analogy would seem to make Latour the Einstein of social theory; a claims which is, to say the least, somewhat overwrought.

\section{What is ANT for?}


It is not always clear how far Latour wishes to press his propositions and provocations. On the one hand he does not shy away from claiming that ANT has effectively deconstructed the whole edifice of modern thought. But then in a fit of humility he readily acknowledges that 'in most situations' the vocabulary of conventional sociology 'is not only reasonable but also indispensable, since it offers convenient shorthand to designate all the ingredients already accepted in the collective realm.' Indeed, he goes as far to write that to jettison sociological categories altogether 'would be silly as well as pedantic' (Latour 2005: 10) and concedes that conventional sociology 'works fine with what has been already assembled, it does not work so well to collect anew the participants in what is not - not yet - a sort of social realm.' (Latour 2005: 12) Just as we only need abandon classical mechanics at certain velocities to arrive at accurate predictions, equally, Latour argues, only at certain points will the 'sociology of the social' fail us. A reasonable compromise perhaps. But even were we to accept Latour's argument about the deficiencies of the 'sociology of the social' in some circumstances, this still calls into question the efficacy of ANT for much sociological research, and raises the difficult question of how we could in any case determine whether or not a 'social realm' has already been assembled and therefore if we need call on Latourian metaphysics rather than more conventional sociological categories. It is not at all clear once one has dispensed with the Latourian straw men and polemics how we can demarcate one sociological approach from the other, or indeed how novel the ANT approach is. Max Weber, hardly an enfant terrible of sociology, advanced similar arguments to Callon and Latour on the hollowness of 'the social' as a concept, taking the term to refer to 'the relationships among persons', and regarding it as meaningful only when 'accompanied by some substantive predicate.' (Weber 1949: 67) Weber regarded the term 'social' as having general application only on the basis of its ambiguity and argued that it offers 'no specific point of view, from which the significance of given elements of culture can be analyzed.' 
(Weber 1949: 68) Other key elements of ANT are also of doubtful originality. Latour himself has described his ethnographic approach and anti-critical orientation as 'simply another way of being faithful to the insights of ethnomethodology' (Latour 1999: 19), and there is plainly some methodological affinity with variants of pragmatism and microsociology, such as symbolic interactionism. Many of the central philosophical insights in ANT we have discussed here, meanwhile, stem from the insistence that what is conventionally called 'society' is a product of contingent and transient 'assemblages'. The vocabulary is certainly innovative, but the basic point that society is in some sense 'constructed' is anything but. Mirowski and Nik-Khah remark that ANT's claim 'that order (natural or otherwise) is made, not found' is rather 'unprepossessing' (Mirowski and NikKhah 2008: 116), and in the context of 21st century sociology it is hard to disagree. Indeed, Callon readily acknowledges that the ANT view of society as 'an achievement' rather than a given is shared with constructivist sociology (Callon 1998c: 267, n.5), which itself is obviously a very broad camp, and hardly marginal.

Is ANT then just a rather eccentric variant of constructivist sociology? Arguably, yes, but it differs in several ways from many approaches conventionally categorised as constructivist. In particular, it does not seek to reduce the 'construction' of society to linguistic or discursive processes, thus exhibiting a degree of realism that is largely lost in radical constructivist accounts, and offering something of a midcourse between materialism and idealism, just as Weber did in his time. From the perspective of empirical sociology, then, ANT has a number of advantages over other 'unorthodox' approaches to social science and social theory. What is not clear, however, is whether there are any significant analytical payoffs stemming from its repudiation of a more straightforwardly realist framework.

\section{Truth and consequences}


Elder-Vass, in his largely sympathetic critique of ANT, notes that critical realism like ANT maintains a sort of 'symmetry' in so far as it holds that people, animals, objects and technology all exist in 'the same ontologically unified world' (Elder-Vass 2014: 199). But critical realism, unlike ANT, posits that things possess certain properties independently of our ideas about them, or the particular 'assemblages' within which they are 'enrolled'. Whilst insisting that objects be afforded agency, Latour and his associates have declined to attribute any essential nature to people or things independent of the actor-networks within which they are enrolled. ANT treats

everything in the social and natural worlds as a continuously generated effect of the webs of relations within which they are located. It assumes that nothing has reality or form outside the enactment of those relations. Its studies explore and characterise the webs and the practices that carry them. (Law 2009: 141)

We need not detain ourselves too much here with the philosophical issues that underpin critical realism and ANT respectively, but it is important to recognise that there are methodological implications arising from them. Central to the ANT project is the notion that rather than wrestling with the vexed question of how we can ever know the nature of things, or establish whether claims about the world are true or false, we should satisfy ourselves merely with describing how explanatory frameworks hold true (or don't) in the real world. As Callon writes, the 'concept of truth (or nontruth)' has been replaced in ANT with 'that of success or failure.' (Callon 2007: 320) This is a perfectly coherent approach to take, but it is not without consequences. The radically descriptive approach which ANT shares with ethnomethodology leaves no room for judgments as to the accuracy or otherwise of the explanatory frameworks into which 'actants' are 'enrolled'. Neither is there any space from which to make normative judgements as to the desirability of any particular outcome or assemblage. This is readily acknowledged by Latour, who in one of his characteristic 
provocations turns Marx's famous maxim on his head, writing that 'social scientists have transformed the world in various ways; the point, however, is to interpret it' (Latour 2005: 42). It is perfectly legitimate of course for scholars to endeavour to describe the world accurately whilst leaving normative judgements to one side, but ANT certainly seems vulnerable to the charge of political complacency. The dictum repeated across the ANT cannon is that the researcher should 'follow the actors', exploring their explanations and associations with a 'voluntarily blindness' (Latour 2005: 57). Sociology, Latour argues elsewhere, should 'abandon its "social groups" and its "interests" and allow the actors to define themselves' (Latour 1993: 51). How far Latour wishes to take this wilful naivety is not always clear since he tends to oscillate between radical provocations and more concessionary positions. In Reassembling the Social he insists that this 'does not mean that social scientists are powerless, [nor] that they are always on the leash of their informants' (Latour 2005: 57). The most appropriate interpretation of this methodological prescription then would seem to be to view it as a fairly straightforward outworking of the ANT philosophy. To put it in terms that ANT scholars would likely reject, the researcher should not use 'truth' as a yardstick to examine actors, but should instead examine how actors themselves construct truth through their alliances and associations.

Collins and Yearley have noted that this disinterested methodology originated with Latour's seminal ethnographic work at the Salk Institute. As a sociologist amongst natural scientists, Latour lacked the capacity to make informed judgements as to the nature of the evidence being adjudicated on in the laboratory and 'proudly proclaimed his failure to understand what he was doing' (Collins and Yearley 1992: 311). The solution to this epistemic inferiority - a broader problem in the sociology of science - was obvious: Latour made a virtue out of a necessity by eliminating truth and untruth from his study. What he, in alliance with other 'actants', then assembled was an internally coherent metaphysics and methodology that was 
later rolled out from the scientific laboratory to the rest of the universe. It was an obvious move. After all, if scientific facts are not discovered but constructed through ontological labour, then so, all the more so, are Durkheim's social facts, the proponents of which are easier prey for Latour et al than the natural scientists.

ANT has thus enrolled itself into a rather peculiar position from where the transformative power of intellectual labour is readily acknowledged - most powerfully in Callon's concept 'performativity' - but the researcher, whilst working in intimate dialogue with empirical reality, is always one step removed from both the accuracy of ideas being put to work and the political or normative implications of the realities being made and remade. Latour in particular seems cheerfully indifferent to the human or ecological consequences of the success or failure of particular 'agencements'. Indeed, one could go as far as to say that whilst he has made some significant contributions to the philosophy and sociology of science, his most ambitious undertaking has been his spirited attack on politically engaged academic work. This reached it apogee in 2004 with his aforementioned article comparing the 'social critique' to conspiracy theory (Latour 2004). ${ }^{4}$

What is so peculiar about this though, is that ANT scholars seem quite willing to engage in critique, but only in the critique of critique. Latour is scornful of 'critical sociology', but when it comes to neoclassical economics, by contrast, we are cautioned against questioning the interpretations being mobilised and urged to follow economists and the assemblages they perform. Callon argues that rather than attacking the reductionism of economics, and its failure to capture the complexities of the social world, sociologists should focus on what economics does, and how it is able to create markets and calculative agents. Rather than denouncing economists' reductionist models, sociologists should explore 'the diversity of calculative agencies forms and distributions', and recognise the market as 'a many-sided, diversified, evolving device which the social sciences as well as the actors themselves 
contribute to reconfigure.' (Callon 1998b: 51) This, however, raises the question: should the sociologists and the economists not be treated symmetrically? For Latour, the 'critical sociologists' indulge in a presumptuous and ultimately incoherent redescription of the material-semiotic networks they study. But do neoclassical economists not do the same? Certainly this is the charge from a good number of sociologists and heterodox economists. Conversely, is sociology not 'performative' in the same manner as economics? Were the early sociologists not creating 'society' and 'the social' as they enrolled politicians, bureaucrats and educated publics into their distinctly modern conception of humanity? Were Bourdieu's late political interventions (Bourdieu et al 1993) not attempts to 'enrol' others into a particular actor-networks in direct opposition to those which were being effectively constructed by corporations, neoliberal politicians and technocrats? From such a perspective, the Latourian disavowal of critique and ANT's committed horizontalism looks less innocent, and it is hard to see how ANT can avoid the charge of political complicity levelled at it by Noys (2014), Fuller (2000), Mirowski (2015) and others.

\section{Reassembling sociology: avoiding reification, but recognising social structure}

One of the great strengths of ANT, it has been argued, is its resolutely empirical approach and its cogent critique of the functionalist/structuralist reification of 'society'. The problem though is that Latour et al stretch this too far. As Elder-Vass has noted (2010: 176-7), ANT ultimately denies, or ignores, the causal power of social structures. 'Society' and 'the social', as Latour argues, may indeed be unsustainable reifications, but it does not follow from that that the same point can be applied to all social collectivities. Apple Inc, the European Central Bank, Eton College, Oxfam, the World Economic Forum, Facebook and the Vatican are all abstractions in that they are not physically bounded objects. But that does not mean they are not real things with distinct properties; and it is difficult to see how one can develop a 
convincing account of the contemporary world without acknowledging the particular characteristics, as well as the power, of such institutions.

This much at least would seem to be compatible with ANT, at least in theory, but the same could not be said of abstract concepts like capitalism, imperialism or patriarchy. Terms such as these should certainly be used with a degree of caution by social scientists, but they are surely only problematic insofar as they shut down rather than open up avenues of inquiry, and it is not at all clear that the jettisoning of such concepts in favour of Latourian neologisms or a thoroughgoing agnosticism would be anything other than a retrogressive step. For adherents of a realist social ontology, these are examples 'real but non-observable mechanisms at work', the existence of which we can postulate by their effects (Archer 2000: 45). But even if we reject the position that 'societal expressions' such as these refer to 'real' non-observable entities (Tsilipakos 2015: 69-116), they can still be held to usefully describe sets of institutional arrangements, relations and practices which share certain common features. Consider, patriarchy, for example. When a sociologist researches gender discrimination she might conduct interviews, undertake ethnographic field work, or run focus groups. She may also conduct surveys or develop statistical models to quantify the likely impact that gender has on certain outcomes. If as a result of these investigations she finds strong evidence of prevailing ideas, structures and practices that disadvantage women compared to men, or she amasses statistical data that suggests that gender is a strong predictor of certain negative outcomes - let's say lower levels of pay and higher levels of sexual violence - she may not have uncovered or revealed an entity or totalising system called 'patriarchy', but one can say that she has discovered a set of social arrangements that can meaningfully be described as such (Walby 1990; 1997). Recognising that patriarchy does not exist as an object in the same way that the person we have been referring to as Bruno Latour presumably exists, does not preclude one using the term to meaningfully 
describe the prevalence of certain patterns of gender relations. What makes the term patriarchy meaningful, or useful, is precisely the prevalence of these institutionalised norms as evidenced by various qualitative research methods and the measurement of certain statistical regularities. Moreover, we can certainly speak meaningfully of patriarchal social structures, especially when gender inequality is institutionalised in legal codes establishing, for example, gendered patterns of ownership and inheritance, or granting men certain rights over women's bodies.

Capitalism, similarly, may not be an 'intractable entity' acting 'surreptitiously' behind the social structures and relations a researcher investigates (Latour 2005: 178), but neither is it, like 'the social', a purely redundant rear-world. Rather it is an abstract concept used to meaningfully characterise an historically constituted and empirically verifiable set of social relations and structures that share some distinct features and causal effects. Law and Latour's rejection of the idea that capitalism can ever be used to explain social phenomena (Law 2009: 147; Latour 2005: 55) is based on something of a straw man argument. The issue is not whether terms like capitalism or patriarchy themselves offer explanations in toto of all microlevel processes, it is whether the concepts can be used to meaningfully characterise a set of social relations and structures which whilst varying significantly in different times and places, still share certain key features. The same point can be made on questions of 'race' and racism, or in principle any categories or organisational principles that result in relative advantages or disadvantages that are reproduced culturally and structurally (for a discussion of the intersection of inequalities from a realist perspective, see Walby 2011: 125-146 and Walby, Armstrong, and Strid 2012). The somewhat more abstract concept of social power is a master category of such dynamics, and has long been dismissed as a 'pliable and empty' term by Latour (1986) who, Lukes notes, 'breezily' suggests that the concept be abandoned (Lukes 2005: 64). But whilst 'power' is no more a total explanatory category than patriarchy 
or capitalism - indeed even less so - the concept remains an indispensable shorthand term to describe how a certain arrangement of norms and institutions afford particular individuals and collectives advantages and disadvantages, as well as an important 'common sense' term to describe how such inequalities are experienced.

Researching power certainly requires detailed empirical work and analytical precision. Any intellectual project offering only deconstruction, denunciation and 'grand theory' will inevitably 'run out of steam', and this has arguably been the fate of post-structuralism in its various guises. But whilst ANT offers a seductive alternative, and can certainly yield some useful insights, its horizontalist, symmetrical approach is ill-suited both to the development of scientific knowledge about social structures, and to the interrogation, empirical or normative, of the centres of contemporary social power. As a philosophy and research programme, ANT is very much in keeping with the contemporary zeitgeist of precarious labour and information-technology driven capital accumulation, and equally is of limited application when it comes to addressing the concomitant challenges of democratic crisis, 'post-truth politics', rising inequalities and environmental catastrophe. It is precisely this contemporary condition to which $21^{\text {st }}$ century sociology must speak. 'Keep the social flat', Latour urges researchers (2005: 165-172). But the world is not flat and competing 'actants' and 'agencements' are not equal. In such a context, the disavowal of critique is a serious, even dangerous, misstep.

\section{Notes}

1. I am grateful to my Aston sociology colleagues and to David Miller, Graham Scambler, and especially Dave Elder-Vass, for comments on an earlier draft of this paper. 
2. Porpora (2015: 54-5) contrasts this 'realism' with the 'positivist' approach against which ANT, and STS more broadly, set itself, arguing that the latter essentially attributes 'agency' to causal laws rather than 'the things of the world'.

3. To be clear, this realist rendering is not quite a faithful reading of ANT, which rejects the notion that anything has a nature which exists outside of the networks in which it is enrolled. As Latour himself puts it, ANT 'does not deal with the nature of knowledge, with things-in-themselves, but with the way all these things are tied to our collectives and to subjects.' (Latour 1993: 4) Similarly, it should be noted that Latour would likely reject the realist take on the symmetry principle subsequently offered here. For a discussion of the ANT concept of agency and the critical realist notion of 'causal powers', see Porpora (2015: 132-4).

4. It is worth noting that although Latour apparently considers Bourdieu a peddler of academic 'conspiracy theory', the latter had himself remarked that 'the fantasy of the conspiracy, the idea that an evil will is responsible for everything that happens in the social world, haunts critical social thought.' (Bourdieu and Wacquant 1992: 102)

\section{Bibliography}

Archer, M. 2000 Being Human: The Problem of Agency. Cambridge: Cambridge University Press.

Bloor, D. 1999 'Anti-Latour', Studies in History and Philosophy of Science 30(1): 81-112.

Blumer, H. 1986 Symbolic Interactionism: Perspective and Method, Berkeley and Los Angeles and London: University of California Press.

Boltanski, L. 2011 On Critique: A Sociology of Emancipation. Cambridge and Malden: Polity Press. 
Boltanski, L. Honneth, A. and Celikates R. 2014 'Sociology of Critique or Critical Theory? Luc Boltanski and Axel Honneth in Conversation with Robin Celikates' in Simon Susen and Bryan S. Turner (eds) The Spirit of Luc Boltanski: Essays on the 'Pragmatic Sociology of Critique', London and New York: Anthem Press.

Bourdieu, P. and Wacquant, L. 1992 An Invitation to Reflexive Sociology, Cambridge: Polity.

Bourdieu, P. et al 1993 The Weight of the World: Social Suffering in Contemporary Society, Stanford: Stanford University Press.

Burawoy, M. 2005 'For public sociology’, American Sociological Review 70(1): 4-28.

Butler, J. 1990 Gender Trouble, London: Routledge.

Butler, J. 1997 Excitable Speech: A Politics of the Performance, New York: Routledge.

Callon, M. 1986 'Some Elements of a Sociology of Translation: Domestication of the Scallops and the Fishermen' in J. Law (ed.) Power, Action and Belief: A New Sociology of Knowledge?. London: Routledge.

Callon, M. 1998a 'Actor-Network Theory - the Market Test', Department of Sociology, Lancaster University. Available at: http://www.lancaster.ac.uk/fass/resources/sociologyonline-papers/papers/callon-markettest.pdf

Callon, M. 1998b 'The embeddedness of economic markets in economics' in M Callon (ed.) The Laws of the Markets, Oxford: Blackwell.

Callon, M. 1998c 'An essay on framing and overflowing' in M. Callon (ed.) The Laws of the Markets, Oxford: Blackwell. 
Callon, M. 2007 'What Does it Mean to Say that Economics is Performative?' in D.

MacKenzie, F. Muniesa and L. Siu (eds) Do Economists Make Markets? On the

Performativity of Economics, Princeton: Princeton University Press.

Collins H.M. and Yearley, S. 1992 ‘Epistemological Chicken’ in A. Pickering (ed.) Science as Practice and Culture, Chicago and London: The University of Chicago Press.

Elder-Vass, D. 2010 The Causal Power of Social Structures: Emergence, Structure and Agency, Cambridge University Press.

Elder-Vass, D. 2014 'Disassembling actor-network theory', Philosophy of the Social Sciences 45(1): 100-121.

Foucault, M. 1980 Power/Knowledge: Selected Interviews and Other Writings 1972-1977, edited by Colin Gordon, translated by Colin Gordon et al. New York: Pantheon Books.

Fuller, A. A. 1996 'Producing Radical Scholarship: The Radical Sociology Movement, 1967-1975', Sociological Imagination 33(1). Available at: http://comm-org.vtoledo.edu/si/ Fuller.htm [Accessed on 22 August 2016].

Fuller, S. 2000 'Why Science Studies Has Never Been Critical of Science', Philosophy of the Social Sciences 30(5): 5-32.

Halsey, A. H. 2004 A History of Sociology in Britain: Science, Literature, and Society, Oxford: Oxford University Press.

Harman, G. 2009 Prince of Networks: Bruno Latour and Metaphysics, Melbourne: Re:Press.

Inglis, D. 2014 'What is Worth Defending in Sociology Today? Presentism, Historical Vision and the Uses of Sociology', Cultural Sociology 8(1): 99-118.

Latour, B. 1986 'The powers of association' in J Law (ed) Power, Action and Belief: A New Sociology of Knowledge?, London: Routledge \& Kegan Paul. 
Latour, B. 1987 Science in Action, Milton Keynes: Open University Press.

Latour, B. 1993 We Have Never Been Modern, translated by Catherine Porter. Cambridge, MA: Harvard University Press.

Latour, B. 1999 'On Recalling A.N.T. ’ in J. Law and J. Hassard (eds) Actor Network Theory and After, Oxford and Malden: Blackwell.

Latour, B. 2003 'Is re-modernization occurring-And if so, how to prove it? A commentary on Ulrich Beck', Theory, Culture \& Society 20(2): 35-48.

Latour, B. 2004 'Why has critique run out of steam? From matters of fact to matters of concern.', Critical Inquiry 30(2): 225-248.

Latour, B. 2005 Reassembling the Social: An Introduction to Actor-Network-Theory, Oxford: Oxford University Press.

Latour, B. et al 2012 "The whole is always smaller than its parts" - a digital test of Gabriel Tardes' monads.', The British Journal of Sociology 63(4): 590-615.

Latour, B. and Woolgar S. 1979 Laboratory Life: The Social Construction of Scientific Facts, Princeton: Princeton University Press.

Law, J. 2008 'On Sociology and STS', Sociological Review 56 (4): 623-49.

Law, J. 2009 ‘Actor Network Theory and Material Semiotics', in B. S. Turner (ed.) The New Blackwell Companion to Social Theory, Oxford: Blackwell-Wiley.

Law, J. and Singleton V. 2013 'ANT and Politics: Working in and on the World', Qualitative Sociology 36(4): 485-502.

Lukes S. 2005 Power: A Radical View, Basingstoke and New York: Palgrave Macmillan.

Mann, M. 1986 The Sources of Social Power, Vol. I: A History of Power from the Beginning to 1760 AD. Cambridge: Cambridge University Press. 
Mirowski, P. 2015 What is Science Critique?: Lessig, Latour, Foucault Part 1. Keynote address to Workshop on the Changing Political Economy of Research and Innovation, UCSD, March 2015

Mirowski, P. and Nik-Khah E. 2008 'Command Performance: Exploring What STS Thinks It Takes to Build a Market', in T. Pinch and R. Swedberg (eds) Living in a Material World: Economic Sociology Meets Science and Technology Studies, Cambridge MA and London: MIT Press.

Mitchell, T. 2002 Rule of Experts: Egypt, Techno-politics, Modernity, Berkeley: University of California Press.

Mitchell, T. 2007 'The properties of markets', in D. MacKenzie, F. Muniesa and L. Siu (eds) Do Economists Make Markets? On the Performativity of Economics, Princeton: Princeton University Press.

Mitchell, T. 2011 Carbon Democracy: Political Power in the Age of Oil, London: Verso.

Muniesa F. 2014 The Provoked Economy: Economic Reality and the Performative Turn, London: Routledge.

Muniesa F. 2016 'Setting the habit of capitalization: the pedagogy of earning power at the Harvard Business School, 1920-1940', Historical Social Research 41(2): 196-217.

Muniesa F. et al 2017 Capitalization: A Cultural Guide, Paris: Presses des Mines.

Noys, B. 2014 'The Discreet Charm of Bruno Latour' in J. Habjan and J. Whyte (eds) (Mis)readings of Marx in Continental Philosophy, Basingstoke and New York: Palgrave MacMillan.

Outhwaite, W. 2009 'Canon formation in late 20th-century British sociology', Sociology 43(6): 1029-1045. 
Pels, D. 2003 Unhastening Science: Autonomy and Reflexivity in the Social Theory of Knowledge, Liverpool: Liverpool University Press.

Piketty, T. 2014 Capital in the Twenty-First Century. Harvard University Press.

Porpora, D.V. 2015 Reconstructing Sociology: The Critical Realist Approach. Cambridge: Cambridge University Press.

Rose N. and Miller P. 2008 Governing the Present: Administering Economic, Social and Personal Life, Cambridge: Polity Press.

Ross, R.J.S. 2010 'Reflections on the Sociology Liberation Movement of 1968', in G. Cassano, R.A. Dello Buono (eds) Crisis, Politics and Critical Sociology, Leiden and Boston: Brill.

Seguin, E. 2000 'Bloor, Latour, and the field', Studies in History and Philosophy of Science 31(3): 503-508.

Swartz, D. L. 2003 'From critical sociology to public intellectual: Pierre Bourdieu and politics', Theory and Society 32(5/6): 791-823.

Tsilipakos, L. 2015 Clarity and Confusion in Social Theory: Taking Concepts Seriously, Farnham: Ashgate.

Walby, S. 1990 Theorizing Patriarchy, Oxford: Blackwell.

Walby, S. 1997 Gender Transformations, Routledge: London

Walby, S. 2011 The Future of Feminism, Cambridge: Polity.

Walby, S., Armstrong, J., and Strid, S. 2012 'Intersectionality: Multiple inequalities in social theory', Sociology, 46(2), 224-240.

Weber, M. 1949 The Methodology of Social Sciences, Glencoe, Illillois: Free Press. 
Weizman, E. 2007 Hollow Land, London: Verso. 